\title{
Evaluation of four improved soybean varieties under different planting date in relayed cropping system with maize under soybean/maize/cassava intercrop
}

\author{
Adeniyan, O. $\mathbf{N}^{\star}$. and Ayoola, O. T. \\ Institute of Agricultural Research and Training, P.M.B. 5029, Moor Plantation, Ibadan, Oyo State, Nigeria. \\ Accepted 9 February, 2007
}

\begin{abstract}
Field experiments were conducted at Ibadan; Southwest Nigeria in 2001 and 2002 to evaluate the effects of relayed intercropping of four improved soybean varieties with maize in soybean/maize/cassava intercropped. Intercropping depressed maize grain yield and cassava fresh tuber yield. The response observed in the yields of maize and cassava under different soybean varieties in intercropping systems with maize and cassava was not significant. Soybean plant height at harvest, number of days to 50 percent flowering, number of pods per plant, weight of 100 seeds and seed yield were significantly affected by intercropping systems. Soybean variety TGX $1019-2 \mathrm{E}$ gave the highest values (66.69, $20.73 \mathrm{~g}$ and $1.02 \mathrm{t} / \mathrm{ha}$ ) for number of pods per plant, weight of $100 \mathrm{seeds}$ and seed yield, respectively, under intercropping systems. The response observed in 2001 and 2002 was significant for weight of 100 seed and seeds yield. The higher values $(18.53 \mathrm{~g}$ and $0.87 \mathrm{t} / \mathrm{ha}$ ) were obtained for $2001 \mathrm{compared}$ to that of 2002. The number of weeds per $1 \mathrm{~m} \times 1 \mathrm{~m}$ guardant significantly varied among intercropping systems. Cassava/soybean relayed with maize under intercropping system gave the least values $(50.29$ and 35.63) at 5 and 7 weeks after sowing respectively. Among the four improved soybean varieties evaluated under intercropping, TGX $1019-2 \mathrm{E}$ and TGX $1448-2 \mathrm{E}$ gave the least values at 7 and 9 weeks after sowing.
\end{abstract}

Key words: Soybean, varieties, planting date, relayed-intercropping, sole cropping.

\section{INTRODUCTION}

Intercropping is a system in which different crop mixtures are grown at the same time on the same piece of land. There are other forms of this system such as relay cropping, which has a marked time of planting component crop, and multiple cropping, in which more than one crop harvest per season is obtained. Under improved technological conditions, the superiority of intercropping as a farming system has been demonstrated (IITA, 1980; Ruthenberg, 1980) and in some cases recommendations had been made (Nnoko and Doto, 1982). According to these authors, intercropping brings about increase in crop yields, crop diversity and the stability of crop production.

One of the many problems encountered in the production of soybeans in the humid tropical environments of West Africa is the wide fluctuation in the germination and

\footnotetext{
*Corresponding author. E-mail: adeniyantayo@yahoo.com.
}

emergence of soybean seeds in the field from year to year such that plant population densities cannot be met (McGee et al., 1980). The causes of these problems include the use of poor quality seeds (Nangju et al., 1980), poor storage conditions (Delouche, 1981), increased incidence of seed-borne fungal infection (Sinclair, 1974) and sowing and harvesting when environmental conditions are unfavorable (Martins et al., 1988).

With serious research effort being placed today on soybean production within the framework of farming system of Southwest Nigeria, renewed interest has been generated in intercropping soybean with other crops. According to Olufajo (1992) in the traditional soybean growing areas of Nigeria, soybean is most commonly intercropped with cereal crops like maize, sorghum and millet. Consequently, there is the need to expand the scope of soybean cultivation through intercropping systems. This is with a view to increasing the production 
Table 1. Monthly and total annual rainfall $(\mathrm{mm})$ in lbadan in 2001 and 2002.

\begin{tabular}{|l|c|c|}
\hline \multicolumn{1}{|c|}{ Month } & $\mathbf{2 0 0 1}$ & $\mathbf{2 0 0 2}$ \\
\hline January & 0.00 & 0.00 \\
February & 7.50 & 0.00 \\
March & 15.1 & 44.3 \\
April & 101.6 & 176.0 \\
May & 206.0 & 138.1 \\
June & 159.3 & 196.6 \\
July & 235.0 & 247.5 \\
August & 42.3 & 125.9 \\
September & 311.2 & 216.5 \\
October & 137.3 & 276.4 \\
November & 46.3 & 76.8 \\
December & 0.00 & 0.00 \\
Total annual & 1261.6 & 1498.1 \\
Mean annual & 105.1 & 124.8 \\
\hline
\end{tabular}

capacity and also to adapt soybean to the farming system of Southwest agro ecological zone of Nigeria.

Studies for crop production recommendations, such as date of planting and weed control must be conducted for improved soybean varieties in intercropping system with maize and cassava. If soybean is ever to become accepted as a basic food commodity or cash crop or both in Southwest Nigeria, then a place must be found for it within the existing farming system. The major question, however, is whether soybean can be planted during the wet season of the cropping years. This is because soybean seeds suffered considerable deterioration on the field as well as during and immediately after harvest (Ojo et al., 2001). The objective of this study therefore is to evaluate the growth and yield performances of improved soybean varieties to different date of planting in relayed intercropping system with maize in soybean /maize/cassava intercrop. In addition, the suppressive ability of soybean varieties in weed management under intercropping system will also be determined.

\section{MATERIALS AND METHOD}

Trials were conducted in 2001 and 2002 at Ibadan (Lat $07^{\circ} 22^{\prime \prime} \mathrm{N}$, $03^{\circ} 50^{\prime \prime E}$ ) in rainforest agro ecological zone of Southwest Nigeria on an alfisol. The mean annual rainfall in Ibadan varies between 1000 and $1300 \mathrm{~mm}$ and distributed over seven months with a short dry spell in August. The sites were ploughed and harrowed. The treatments consisted four cropping systems, which are:

\section{i. Cassava/maize/soybean}

ii. Cassava/maize relayed with soybean

iii. Cassava/soybean relayed with maize

iv. Sole cassava, sole maize and sole soybean.

The cassava variety was TMS30572 and the maize variety was SUWAN - 1. The soybean varieties were TGX $1448-2 E$ (Medium maturing, erect type), TGX $1445-2 \mathrm{E}$ (Late maturing, erect type),
Table 2. Effect of four improved soybean varieties in intercropping with maize and cassava on yields of maize and cassava.

\begin{tabular}{|l|c|c|}
\hline \multicolumn{1}{|c|}{ Treatments } & Maize & Cassava \\
\hline Cropping systems & & \\
Cassava/maize/soybean & $2.14 \mathrm{c}$ & $15.47 \mathrm{c}$ \\
Cassava/maize relayed with soybean & $2.25 \mathrm{~b}$ & $17.93 \mathrm{~b}$ \\
Cassava/soybean relayed with maize & $2.36 \mathrm{~b}$ & $15.40 \mathrm{c}$ \\
Sole crop & $2.75 \mathrm{a}$ & $22.15 \mathrm{a}$ \\
\hline Soybean varieties in intercropping & & \\
system & & \\
TGX 1448-2E & $2.30 \mathrm{~b}$ & $17.59 \mathrm{a}$ \\
TGX 1445-2E & $2.33 \mathrm{~b}$ & $16.02 \mathrm{~b}$ \\
TGX 1485-1D & $2.23 \mathrm{~b}$ & $16.21 \mathrm{~b}$ \\
TGX 1019-2E & $2.23 \mathrm{~b}$ & $16.09 \mathrm{~b}$ \\
\hline Year & & \\
2001 & $2.44 \mathrm{a}$ & $15.77 \mathrm{~b}$ \\
2002 & $2.15 \mathrm{~b}$ & $16.83 \mathrm{a}$ \\
\hline
\end{tabular}

Means having the same letter are not significantly different

$(P=0.05)$ according to Duncan's Multiple Range Test.

TGX 1485 - 1D (Early maturing, erect type) and TGX 1019 - 2E (Early maturing, broad leaf, erect type).

The intercrop and sole crop were laid out in a randomized complete block design (RCBD) replicated three times, with plot size $4 \mathrm{~m} \times 5 \mathrm{~m}$. The establishment of maize/cassava/soybean, cassava /maize and cassava/soybean intercrops was done on the second week of May in 2001 and 2002. Relayed cropping of maize or soybean was done on the first week of September of 2001 and 2002. Cassava and maize plants were spaced $1 \mathrm{~m} \times 1 \mathrm{~m}$ apart. The soybean row was in between cassava and maize at $50 \mathrm{~cm}$ inter-row spacing. After three weeks after planting $150 \mathrm{~kg} / \mathrm{ha}$ NPK $15-15-$ 15 fertilizer was applied to maize and cassava. At maize tasselling, $60 \mathrm{~kg} / \mathrm{ha}$ of urea was applied as second dose application to maize. At maturity, yield data was taken on maize and cassava. Data collected on soybean were plant height at harvest, number of days to $50 \%$ flowering, number of pods per plant, weight of 100 seeds and seed yield. Using $1 \mathrm{~m} \times 1 \mathrm{~m}$ quadrant, data collected on weeds were; weed population density at 5,7 and 9 weeks after sowing. The data obtained were analyzed for variance.

\section{RESULT AND DISCUSSION}

The monthly rainfall distribution at Ibadan, Nigeria in 2001 and 2002 is shown in Table 1. The total annual rainfall in 2001 and 2002 were 1261.6 and $1498.1 \mathrm{~mm}$ respectively. Table 2 shows that sole cropping of maize and cassava were significantly superior to that of cassava/maize/soybean intercrop, cassava/maize relayed with soybean and cassava/soybean relayed with maize. The values $(2.75 \mathrm{t} / \mathrm{ha}$ and $22.15 \mathrm{t} / \mathrm{ha})$ for maize and cassava respectively from sole cropping were the highest compared to the least values (2.14 t/ha and 15.47 t/ha) recorded for cassava/maize/soybean intercrop. The overall superior performance of sole cropping compared to intercropping systems had been similarly reported by other workers (Singh et al., 1973; Mohta and De, 1980). The depressed yields of maize and cassava when inter- 
Table 3. Effect of four improved soybean varieties in intercropping with maize and cassava on growth and yield of soybean.

\begin{tabular}{|l|c|c|c|c|c|}
\hline \multicolumn{1}{|c|}{ Treatment } & $\begin{array}{c}\text { Soybean plant } \\
\text { height at } \\
\text { harvest } \mathbf{( c m )}\end{array}$ & $\begin{array}{c}\text { Number of } \\
\text { days to } 50 \% \\
\text { flowering }\end{array}$ & $\begin{array}{c}\text { Number of } \\
\text { pods per } \\
\text { plant }\end{array}$ & $\begin{array}{c}\text { Weight of } \\
\mathbf{1 0 0} \text { seed } \\
\text { (g) }\end{array}$ & $\begin{array}{c}\text { Soybean } \\
\text { seed yield } \\
\text { (t/ha) }\end{array}$ \\
\hline Cropping systems & & & & & \\
Cassava/maize/soybean & $52.18 \mathrm{a}$ & $45.89 \mathrm{~b}$ & $54.94 \mathrm{~b}$ & $16.78 \mathrm{c}$ & $0.79 \mathrm{c}$ \\
Cassava/maize relayed with soybean & $52.24 \mathrm{a}$ & $46.46 \mathrm{~b}$ & $59.73 \mathrm{a}$ & $19.92 \mathrm{~b}$ & $1.24 \mathrm{a}$ \\
Cassava/soybean relayed with maize & $48.44 \mathrm{~b}$ & $48.96 \mathrm{a}$ & $46.31 \mathrm{c}$ & $12.95 \mathrm{~d}$ & $0.55 \mathrm{~d}$ \\
Sole crop & $50.19 \mathrm{ab}$ & $4589 \mathrm{~b}$ & $55.98 \mathrm{~b}$ & $21.47 \mathrm{a}$ & $0.96 \mathrm{~b}$ \\
\hline Soybean varieties in intercropping & & & & & \\
system & & & & & \\
TGX 1448-2E & $52.66 \mathrm{~b}$ & $43.73 \mathrm{c}$ & $61.17 \mathrm{~b}$ & $18.53 \mathrm{~b}$ & $0.78 \mathrm{c}$ \\
TGX 1445-2E & $62.25 \mathrm{a}$ & $55.06 \mathrm{a}$ & $46.46 \mathrm{c}$ & $16.26 \mathrm{c}$ & $0.83 \mathrm{~b}$ \\
TGX 1485-1D & $44.31 \mathrm{c}$ & $44.75 \mathrm{~b}$ & $42.65 \mathrm{~d}$ & $15.59 \mathrm{~d}$ & $0.70 \mathrm{~d}$ \\
TGX 1019-2E & $43.82 \mathrm{c}$ & $43.67 \mathrm{c}$ & $66.69 \mathrm{a}$ & $20.73 \mathrm{a}$ & $1.02 \mathrm{a}$ \\
\hline Year & & & & & \\
2001 & $51.51 \mathrm{a}$ & $47.12 \mathrm{a}$ & $54.14 \mathrm{a}$ & $18.58 \mathrm{a}$ & $0.87 \mathrm{a}$ \\
2002 & $50.01 \mathrm{a}$ & $44.49 \mathrm{~b}$ & $54.34 \mathrm{a}$ & $16.98 \mathrm{~b}$ & $0.79 \mathrm{~b}$ \\
\hline
\end{tabular}

cropped with soybean at the same time had been attributed mainly to competition for basic growth resources like nutrients, light and space (Mohta and De, 1980; Olufajo, 1992; Ezumah and McGuire, 1982). The values (2.25 t/ha and $17.93 \mathrm{t} / \mathrm{ha}$ ) for maize and cassava yields respectively under cassava/maize relayed with soybean and the values (2.36 and $15.40 \mathrm{t} / \mathrm{ha}$ ) under cassava /soybean relayed with maize were not significantly different. This may be primarily attributed to the ability of maize to be grown successfully either during the first season as first maize crop or second season as second maize crop. However, cassava has a long maturity period, therefore it can recover from the intercropping effects after maize and soybean has been harvested.

The response observed in the yields of maize and cassava under different soybeans varieties in intercropping systems, however, was not significantly different. Consequently, all the soybean varieties investigated exerted the same kind of depressant effects on maize and cassava yields when intercropped. Result also showed that on the average maize grain yield (2.44 t/ha) obtained in year 2001 was significantly higher than that of $2002(2.15 \mathrm{t} / \mathrm{ha})$. Conversely, cassava fresh tuber yield in $2002(16.83 \mathrm{t} / \mathrm{ha})$ was significantly higher than that of 2001 (15.77 t/ha).

Table 3 shows that soybean plant height at harvest; number of days to 50 percent flowering, number of pods per plant, weight of 100 seeds and yields were significantly affected by the cropping system. The values obtained from cassava/maize/soybean, cassava/soybean relayed with maize and the first season sole soybean were significantly higher than that of cassava/maize relayed with soybean and second season sole soybean for plant height at harvest. Contrarily, higher values were obtained from cassava/maize relayed with soybean and second season sole soybean for number of days to 50 percent flowering, number of pods per plant, weight of 100 seeds and seed yield compared to cassava/maize /soybean and cassava/soybean relayed with maize cropping systems. The results indicated that regardless of soybean variety, the performance and yield of soybean would be affected by the date of planting. It has been noted also that the quality of soybean seed and plant is very much affected by climatic conditions from the times of planting to the time of harvesting. Delouche (1980) had suggested that frequent or prolonged rainfall during the post-maturation and pre-harvest period results in alternate wetting and drying of the seed in the pod and severe deterioration. This is an indication that the yield of soybean grown during the first cropping season of the year will be reduced compared to the one grown during the second cropping season. The frequent and or prolonged rainfall during the first season would extend or prevent the ability of the plant to flower; however, this would encourage the vegetative growth of the plant to the disadvantage of seed production.

Soybean variety TGX1019 - 2E gave the highest values $(66.69,20.73 \mathrm{~g}$ and $1.02 \mathrm{t} / \mathrm{ha}$ ) for number of pods per plant, weight of 100 seeds and seed yield respectively under intercropping and relayed cropping systems. The response observed in year 2001 and 2002 were significantly different for number of days to 50 percent flowering, weight of 100 seeds and seed yield. The higher values $(18.58 \mathrm{~g})$ for weight of 100 seeds and $(0.87 \mathrm{t} / \mathrm{ha})$ for seed yield were obtained from 2001 compared to that of 2002. The yield difference obtained might essentially be attributed to low rainfall value $(42.30 \mathrm{~mm})$ recorded in the month of August 2001 compared to rainfall value 
Table 4. Effect of four improved soybean varieties in intercropping with maize and cassava on weed control.

\begin{tabular}{|l|c|c|c|}
\hline \multicolumn{1}{|c|}{ Treatments } & $\begin{array}{c}\text { 5 Week after planting } \\
\text { (WAS) }\end{array}$ & $\begin{array}{c}\text { 7 Week after } \\
\text { planting (WAS) }\end{array}$ & $\begin{array}{c}\mathbf{9} \text { Week after } \\
\text { planting (WAS) }\end{array}$ \\
\hline Cropping systems & & & \\
Cassava/maize/soybean & $64.71 \mathrm{~b}$ & $46.63 \mathrm{~b}$ & $19.65 \mathrm{~b}$ \\
Cassava/maize relayed with soybean & $134.5 \mathrm{a}$ & $146.1 \mathrm{a}$ & $158.7 \mathrm{a}$ \\
Cassava/soybean relayed with maize & $50.29 \mathrm{c}$ & $35.63 \mathrm{~cd}$ & $16.94 \mathrm{~b}$ \\
Sole TGX 1448-2E & $49.08 \mathrm{c}$ & $38.83 \mathrm{c}$ & $16.94 \mathrm{~b}$ \\
Sole TGX 1445-2E & $49.92 \mathrm{c}$ & $35.83 \mathrm{~cd}$ & $18.42 \mathrm{~b}$ \\
Sole TGX 1485-1D & $48.50 \mathrm{c}$ & $33.50 \mathrm{de}$ & $17.33 \mathrm{~b}$ \\
Sole TGX 1019-2E & $46.75 \mathrm{c}$ & $29.75 \mathrm{e}$ & $15.50 \mathrm{~b}$ \\
\hline Soybean varieties in intercropping & & & \\
system & & & \\
TGX 1448 - 2E & $63.45 \mathrm{~b}$ & $45.50 \mathrm{~b}$ & $13.15 \mathrm{~b}$ \\
TGX 1445-2E & $66.17 \mathrm{a}$ & $49.39 \mathrm{a}$ & $19.56 \mathrm{a}$ \\
TGX 1485-1D & $66.67 \mathrm{~b}$ & $48.19 \mathrm{a}$ & $19.40 \mathrm{a}$ \\
TGX 1019-2E & $63.67 \mathrm{~b}$ & $45.13 \mathrm{~b}$ & $13.42 \mathrm{~b}$ \\
\hline
\end{tabular}

Means having the same letter are not significantly different $(P=0.05)$ according to Duncan's multiple range tests.

$(125.9 \mathrm{~mm})$ in the same month in 2002 . This particular month marked the post-maturation and pre-harvest period for the first season soybean planted in May of each year. The adverse effects of inclement weather during the harvest period on seed yield and quality have been discussed (Delouche, 1980).

The number of weeds per $1 \mathrm{~m} \times 1 \mathrm{~m}$ quadrant significantly varied among intercropping systems (Table 4). However, cassava/soybean relayed with maize gave the least values (50.29 and 35.63) at 5 and 7 weeks after sowing respectively compared to cassava/maize/soybean intercrop. The response observed under the soybean sole crop was not significantly different from that of cassava/soybean relayed with maize. Highest weed population density was observed from cassava/maize with relayed soybean at 5,7 , and 9 weeks after sowing. The relatively low population density of weeds obtained form cassava/maize/soybean and cassava/soybean relayed with maize intercrops had been noted by Finlay (1974). He reported that soybeans were well grown with early weeding because of their relatively slow early development, and after 6 to 8 weeks, act as smother crop with a close canopy. He also suggested that crop competition is the cheapest and most useful method the small farmer has to control weeds. Among the four improved soybean varieties evaluated, TGX1019 - 2E (45.13 and 13.42) and TGX $1448-2 E$ (45.50 and 13.15) had the least values for weed population density at 7 and 9 weeks after planting compared to other varieties. Apparently, this might be due to the physiological feature of the varieties. TGX1019 - 2E variety grew relatively very fast with broad leaves that quickly covered the ground and TGX $1448-2 \mathrm{E}$ produced relatively longer plants.
In conclusion, the results of this study showed that though not developed specifically for intercropping, the newly improved soybean varieties could maintain their high potential under intercropping systems. Where soybean seed quality and high yield are not the primary aim of the farmer, soybean could be planted during the first cropping season as in the case of cassava/maize /soybean or cassava/soybean relayed with maize. This could be incorporated in the existing farming system where animal husbandry is inclusive. The harvested soybean seeds could be fed to the livestock as complementary feed. Furthermore, under intercropping systems that consist of soybean as one of the components, biological weed control is very effective through smothering effect that soybean has on weeds.

Under the climatic conditions of the Southwest Nigeria, especially lbadan, it appears that early season planting of soybean could be hampered by frequent rainfall. Therefore, whenever high yield and good quality soybean seed is important in intercropping system that consists soybean as one of the component crops, relay intercropping system is essential for adoption. Cassava/maize relayed with soybean is recommended. However, in areas with similar conditions with that of Guinea savanna known as derived savanna or transitional savanna of Southwest agro-ecology, early season planting of soybean can be carried out. In intercropping systems, yield advantages will be gained by growing soybean, maize and cassava together.

\section{ACKNOWLEDGEMENT}

We wish to acknowledge the support of all the technical staff of the Farming Systems Research and Extension 


\section{Programme of Institute of Agricultural Research and Training Ibadan for the success of this trial.}

\section{REFERENCES}

Delouche JC (1980). Physiological changes during storage that affect soybean seed quality. Soybean seed quality and stand establishment. INTSOY Series 22: 12-19.

Ezumah HE, McGuire (1982). Competitive relationship of intercropped maize and soybean of different maturity times. In: Proceedings Second Meeting of the Nigeria Soybean. 2: 92-99.

Finlay RC (1974). Intercropping soybean with cereals. Proceedings of a Conference for Scientists of Africa, Middle East and South Asia October 14-17, 1974. Addis Ababa, Ethiopia. pp. 77-85.

IITA (International Institute of Tropical Agriculture) (1980). Annual Report. pp. 10 - 15. IITA, Ibadan Nigeria.

Martins RA, Smith OS, O'Neil M (1988). Relationships between laboratory tests and field emergence of maize inbreds. Crop Sci. 28: 801-805

McGee DC, Brandt CL, Burris JS (1980). Seed mycofloral of soybeans relative to fungal interactions, seedling emergence and carryover of pathogens for subsequent crops. Phytopathology 70: 615-617.

Mohta NK, De R (1980). Intercropping maize and sorghum with soybean. J. Agric. Sci. Camb; 95: 117-122.

Nangju D, Wien HC, Ndimande B (1980). Improved practice of soybean seed production in the tropics. In Seed Production. (Ed. Hebblethwaite PO). London Butterworth pp. 427-448.
Nnoko EN, Doto AB (1982). Intercropping maize or millet with soybean with particular reference to planting schedule. IDRC 186e: 33-36.

Ojo DK, Ellis RH, Ajala MO (2001). Effect of time of harvest on seed germination and capacity for seedling emergence in tropical soybean genotypes. Moor J. Agric. Res. 2: 8-14.

Olufajo OO (1992). Response of soybean intercropping with maize on a sub-humid tropical environment. Trop. Oilseeds J. Vol. 1(1): 27-33.

Ruthenberg $H$ (1980). Farming systems in the tropics, $3^{\text {rd }}$ edition. Oxford Clare don press. p. 424.

Sinclair JB (1974). Some important seed- and soil-borne bacterial and fungal pathogens of soybeans. Proceedings of a Conference for Scientists of Africa, Middle East and South Asia October 14-17, 1974. Addis Ababa, Ethiopia. pp. 124-131.

Singh JN, Negi PS, Tripathi SK (1973). Study on the intercropping of soybean with maize and jower. India J. Agron. 18: 75-78. 